Electrical Engineering. The degree of D.Sc. of the University has been conferred on F. R. N. Nabarro (metallurgy) and F. J. Richards (botany).

\section{Nuffield Foundation Awards in Dentistry, Biology and the Social Sciences}

Tr E Nuffield Foundation is offering a number of fellowships, scholarships and bursaries in the fields of dentistry, biology and the social sciences as follows. The fellowships for dentistry are for persons, aged 25-35 years, with dental qualifications, to receive additional training in pure and applied science so as to undertake an academic career in dentistry, and also to enable graduates in medicine or science to receive training (not necessarily for a registrable dental qualification) that will fit them for teaching and research in dental health and disease; the fellowships are worth $£ 500-800$ a year for one to three years, and applications must be received by March 1. Dental scholarships, normally for one year only, are available for students at university dental schools in the United Kingdom and cover tuition fees and a subsistence allowance of not more than $£ 200$; applications must be received by June 30 . The Foundation's scholarships and bursaries in biology and the social sciences are for graduates of British universities, preferably within the age-group of 22-35 years. The awards in biology are for persons who have graduated in physics, chemistry or mathematics but who have had no training in a biological subject, and who wish to receive such training in biology as will enable them to undertake research and teaching in the United Kingdom in the biological sciences; the scholarships are for persons with some previous experience in postgraduate research in their own subject, and the bursaries for those who have recently graduated, and in both cases the Foundation will pay the cost of university and/or college fees in addition to a maintenance award ; applications must be received by April 1. The awards for the social scicnces are the same as those for biology except that the application forms must be received by May 1 and the holder may have a degree in any subject other than the social sciences, psychology or economics, though one in the natural sciences or mathematics is preferable; subjects suitable for study are political science, social psychology, anthropology, social statistics and sociolngy generally, but not economics. Application forms for all these awards and further information can be obtained from the Secretary, Nuffield Foundation, Nuffield Lodge, Regent's Park, London, N.W.1.

\section{Sociological Research in Africa South of the Sahara}

A MEETING of specialists engaged in the planning of sociological research will be held during the last week of this month in Kampala, Uganda, by the Scientific Council for Africa South of the Sahara, on the occasion of the second seminar of Belgian and British sociological research workers. The meeting will consider present major problems and projects of sociological research in Africa south of the Sahara, and will make suggestions for special studies and means of co-ordination concerning sociological research. Among those who are expected to attend will be Gouverneur Deschamps from the Ministère de la France d'Outre-Mer, Paris; Prof. Griaule, professor of ethnolngy in the University of Paris; Dr. L. van den Berghe, director of the Institut pour la Recherche Scientifique en Afrique Centrale, Congo
Belge; Dr. A. I. Richards, director of the East African Institute of Social Research, Kampala ; Prof. A. Mendes Correa, director of the École Supérieure Coloniale, Lisbon; Mr. V. R. Sutton, of the South African National Institute for Personnel Research; and Dr. Clyde Mitchell, director of the RhodesLivingstone Museum, Northern Rhodesia.

\section{Announcements}

Dr. E. MARSDEN, representative of New Zealand on the Executive Council of the Commonwealth Agricultural Bureaux, Farnham Royal, Bucks, has been elected chairman of the Council in succession to Mr. J. E. Cummins, representative of the Commonwealth of Australia. Mr. W. F. C. Morton (Union of South Africa) follows Dr. G. R. Bates (Southern Rhodesia) as vice-chairman of the Council.

Applucations are invited for Lady Tata Memorial Fund grants, scholarships and fellowships to scientific workers of any nationality for research on diseases of the blood, with special reference to leukæmia, in the academic year beginning October 1 next. Grants are made for research expenses, scholarships are awarded as personal remuneration, their normal value being $£ 600$ for whole-time research, and fellowships will be for workers with considerable research experience, the stipend being $£ 1,000$ a year. Applications must be submitted before March 31, and the awards will be announced in June. Forms of application and further information can be obtained from the Secretary of the Scientific Advisory Committee, c/o Medical Research Council, 38 Old Queen Street, Westminster, London, S.W.I.

No. 6 of the "Bibliography. of Scientific Publications of South Asia", covering India, Burma and Ceylon for the period July-December 1951 (pp. 124. Delhi : South Asia Science Co-operation Cffice, 1952), includes a catalogue of scientific periodicals besides the usual classified list of titles and supplementary list of new periodicals and changes of name, address, frequency, etc. The periodicals are listed alphabetically by title, and details of scientific periodicals which have ceased to appear but which are still of interest to scientific workers are included. Besides particulars of frequency, size and purpose of the periodicals listed, the catalogue gives the publisher's address and the first date of publication.

LIKE many of its contemporaries in the petroleum field, The Lamp, which is the house organ of the Standard Oil Co. (New Jersey), combines knowledge with entertainment. Issue No. 3 for 1952 is particularly characterized by reproductions of life in the Canary Islands, painted by Jnhn Groth. Other features describe a push-button parking-system for cars, in a tall building twenty-five feet wide in Washington, D.C., where seventy-two cars can be automatically garaged in a space which, on the ground, would only accommodate nine; this innovation could well engage the attention of local authorities in congested cities in Great Britain. There is an article on Bermondsey, one of London's oldest boroughs, some account of the Company's oil explorations in foreign lands, and an interesting section on 'hurricane hunters' by the United States Air Weather Service in the Caribbean region.

ERratum. We much regret that in the communication entitled "Height of the Potential Barrier in Barrier Layer Cells" in Nature of January 31, p. 219, the graph has been inverted. 